\title{
PRESENCE OF A MEMBER OF THE GENUS SALIWECKELIA (AMPHIPODA) ON TORTUGA, VENEZUELA
}

\section{SYLVIA E. N. VAN LIESHOUT}

Institute of Taxonomic Zoology, University of Amsterdam, P.O. Box 20125, 1000 HC Amsterdam, The Netherlands

\section{SUMMARY}

A population of Saliweckelia (Amphipoda) from Tortuga (Venezuela) is compared with populations from Curaçao and Bonaire (Netherlands Antilles). Considerable variability in a number of characters, within and between the different populations, makes it difficult to ascertain the taxonomic status of the Tortugan specimens. It may not be excluded that all three populations belong to one variable species.

\section{RÉSUMÉ}

On compare une population de Saliweckelia (Amphipoda) de l'île de Tortuga (Venezuela) avec des populations de Curaçao et de Bonaire (Antilles Néerlandaises). A cause d'une considérable variabilité intra- et interpopulationnelle d'un certain nombre de caractères, il est difficile de se prononcer sur le statut taxonomique des exemplaires de Tortuga. Il n'est pas impossible que les trois populations appartiennent à une espèce unique et variable.

\section{INTRODUCTION}

During the Amsterdam Expedition to the West Indian Islands of 1982, a number of islands of the Leeward Group in the West Indies, belonging to Venezuela, were visited. On one of these islands, Tortuga, specimens of a member of the genus Saliweckelia Stock, 1977, were obtained. The presence of Saliweckelia on Tortuga was already briefly mentioned in a zoogeographical analysis (Stock, 1982: 195, table II), but no more detailed taxonomic data were made available in that paper. In the light of the fact that the two previously described species of the genus were hitherto considered endemic to

*) Report 28 is published in the same issue of this journal.
Curaçao and Bonaire, a morphological comparison with the material from Tortuga is of some interest.

\section{MATERIAL EXAMINED}

Samples were collected by the participants of the Amsterdam Expedition to the West Indian Islands, 1982, on Tortuga:

Sta. 82-02, Landing Bay $\left(10^{\circ} 55^{\prime} 29^{\prime \prime} \mathrm{N} 65^{\circ} 25^{\prime} 05^{\prime \prime} \mathrm{W}\right)$, near the western tip of the island, somewhat E. of Pta. Arenas, in a hole dug in coarse sand of the beach (method Karaman-Chappuis), $1.5 \mathrm{~m}$ above the water line; chlorinity 23,928 $\mathrm{mg} / \mathrm{l} ; 17$ Feb. 1982; about 60 specimens (Zoölogisch Museum Amsterdam coll. no. Amph. 107.588).

Sta. 82-05, El Carenero $\left(10^{\circ} 53^{\prime} 54^{\prime \prime} \mathrm{N} 65^{\circ} 14^{\prime} 43^{\prime \prime} \mathrm{W}\right)$, in the S.W. part of the island, in a crevice on the landward side of an elevated fossil Acropora terrace; chlorinity $30,176 \mathrm{mg} / \mathrm{l} ; 18 \mathrm{Feb} .1982$; 1 specimen (Zoölogisch Museum Amsterdam coll. no. Amph. 107.589).

Sta. 82-06, El Carenero, near previous station but on the seaward side of the elevated coral terrace, on the very beach, Bou-Rouch biophreatical pump in coral rubble, about $0.3 \mathrm{~m}$ above the water line; approximately marine salinity; 18 Feb. 1982; 1 specimen (Zoölogisch Museum Amsterdam coll. no. Amph. 107.590).

\section{RESULTS}

During the first comparison of the Tortugan specimens with Saliweckelia emarginata Stock, 1977 (from Curaçao), and S. holsingeri Stock, 1977 (from Bonaire), some minor differences were found, but upon closer inspection these proved to fall within the variability of both species. Because most of these characters repre- 
sent intermediate states between $S$. emarginata and $S$. holsingeri, it may be useful to enumerate the differences found.

1. The number of articles in the flagellum of the first antenna in the two previously described species and the specimens from Tortuga are not significantly different (18 to 27 in $S$. emarginata; 22 in the holotype, the only male available, of $S$. holsingeri; 16 to 22 in the Tortugan specimens).

2. The number of articles in the flagellum of the second antenna is 11 to 20 (emarginata), 9 (holsingeri), and 8 to 11 (Tortuga), respectively. However, in one of the specimens of $S$. emarginata from Curaçao, examined for this purpose, the left and right flagella consisted of 8 and 9 articles only.

3. The carpus of the first gnathopod in the female of $S$. emarginata is provided with about 15 rows of setae; in $S$. holsingeri there are 7 to 8 such rows, and in the specimens from Tortuga the number of rows ranges between 5 and 8 , but mostly 7 rows are present.

4. The propodus of the second gnathopod in the female has 14 (emarginata), 5 (holsingeri), and 10 (Tortuga) rows of setae; in the male there are 6 (emarginata), 3 (holsingeri), and 6 to 11 (Tortuga) rows of setae present.

5. The number of spines on the anterior margin of the basis of pereiopods 5 to 7 ranges from 8 to 10 in $S$. emarginata, from 5 to 7 in $S$. holsingeri, and from 5 to 7 in the Tortugan specimens.

6. The endopodite of the third uropod has a pointed tip in $S$. emarginata, but a truncate tip in $S$. holsingeri. In the specimens from Tortuga both types of tips were found, even in one and the same specimen.

7. The degree of emargination of the fourth coxal plate in the specimens from Tortuga is less deep than in S. emarginata, and hence more like that of $S$. holsingeri.

8. The robust spine ("basofacial spine") at the basis of the first uropod is smaller in the specimens from Tortuga than in the typespecimens of $S$. emarginata and in the (juvenile) paratypes of $S$. holsingeri. However, another specimen of $S$. emarginata examined showed a much smaller spine, notably of the same size as that of the Tortugan specimens.
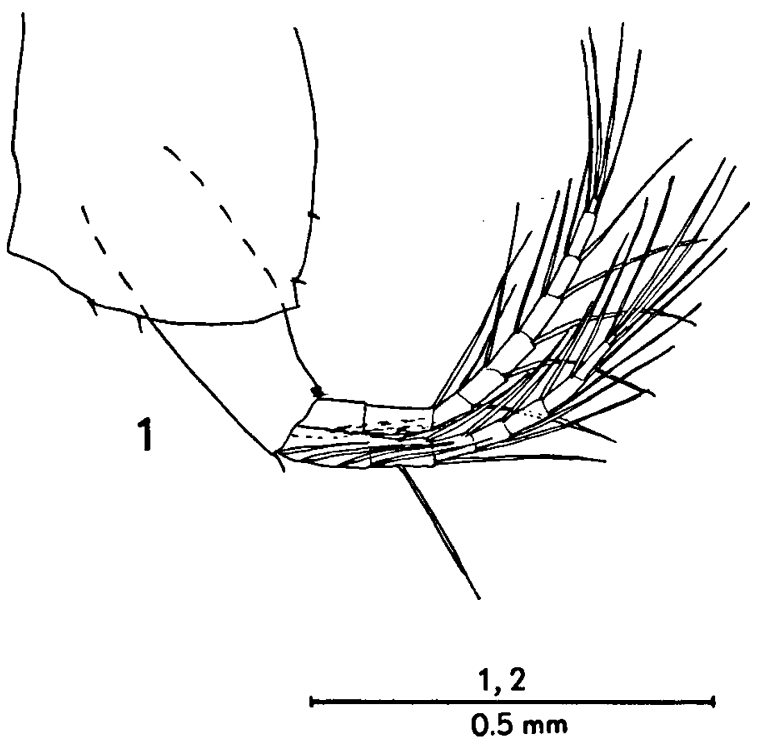

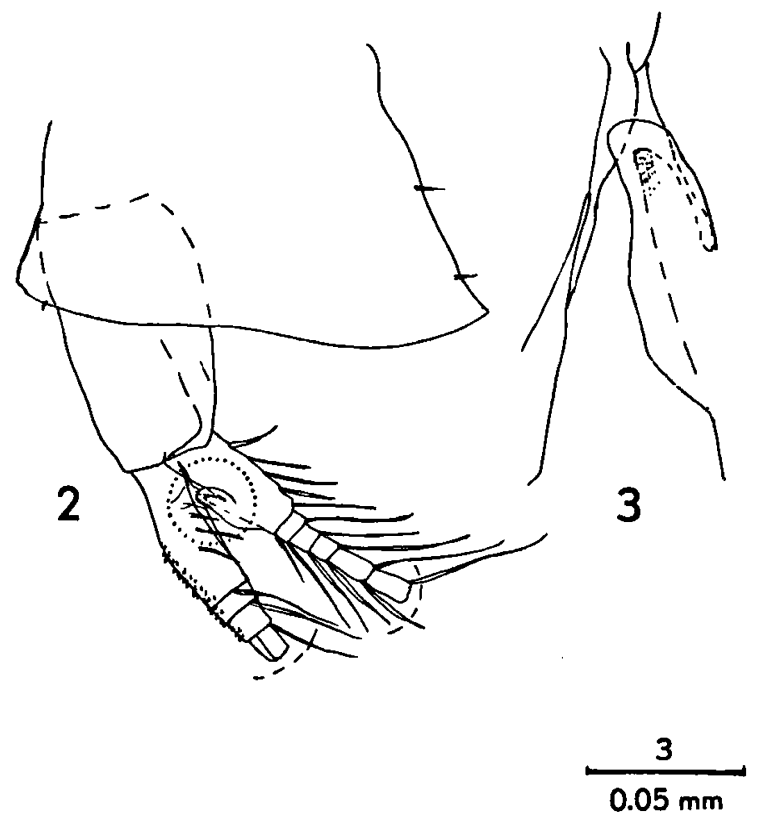

Figs. 1-3. Saliweckelia spec. from Tortuga, $\sigma^{\prime}: 1$, second left epimeral plate and second pleopod; 2, third left epimeral plate and third pleopod (distal part of the rami omitted); 3, detail of basal segments of the rami of the third pleopod (see encircled portion in fig. 2). 
9. The mandibular palp and the maxillipedal palp are more burly in the specimens from Tortuga than in either $S$. emarginata or $S$. holsingeri.

10. The third male pleopod in the Tortugan specimens (figs. 2,3 ) is very similar to that of $S$. emarginata. This became clear only after examination of a freshly dissected specimen of the latter, because the somewhat complex lobes on the pleopodal rami show up differently in every slide made. By lack of adult males of $S$. holsingeri it could not be determined whether the seemingly different appearance is real or an artefact.

11. The epimeral plates 2 and 3 in the specimens from Tortuga have a somewhat pointed posteroventral corner (figs. 1, 2), more produced than those in $S$. emarginata, but less acute than those in $S$. holsingeri. The anterior and posterior margins of the epimera are rather straight, even straighter than in $S$. emarginata.

\section{DISCUSSION}

On account of the shape of the third pleopod in the male, and of the epimeral plates, it would be plausible to conclude that the specimens found on Tortuga belong to $S$. emarginata. However, because of the emargination of the fourth coxal plate, and of the number of rows of setae on the carpus of gnathopod 1, they seem to belong to $S$. holsingeri. Other characters tend to be intermediate between the two species. The number of articles in the flagella of the first and second antennae gives no indication (and is very much age-dependent), and neither does the shape of the tip of the third uropod. This leads to the conclusion that the variability within each species, or within each population, is high and that several of the characters have no high taxonomic value.

\section{CONCLUSION}

Owing to the minor nature of the differences found between the specimens from Tortuga and the two already described species, we have refrained from describing a new species for the Tortugan material. Since we regard the structure of the lobes on the rami of the third male pleopod as the most significant character, the Tortugan specimens can best be regarded as a slight variation of, and incorporated in, $S$. emarginata, at least until more morphological data are available on $S$. holsingeri. Possibly a computer analysis of the intraspecific variability might clarify some of the problems.

The observed variation throws doubt upon the segregation of $S$. emarginata and $S$. holsingeri. All known localities of Saliweckelia are of a similar nature: euhaline or hypersaline habitats in close contact with the sea. The possibility of gene flow through marine connections is not quite improbable. Therefore, $S$. holsingeri could well represent a mere variant population of $S$. emarginata, or eventually a subspecies.

\section{ACKNOWLEDGEMENTS}

The fieldwork on which the present publication is based has been financially supported by the Treub Maatschappij (Utrecht), the Beijerinck-Popping Fonds (Amsterdam), and the Amsterdamse Universiteits Vereniging (Amsterdam).

The sampling program has been carried out by the author and the following other members of our team: Dr. L. Botosaneanu, Drs. N. Broodbakker, Ir. J. Notenboom, Mr. M. Stock, Prof. Dr. J. H. Stock (expedition leader), Dr. S. Weinberg and Mrs. F. Zijlstra.

The organization of the fieldwork in Venezuela has greatly benefited from support rendered by H.M. Embassy of The Netherlands, Caracas, in particular by Dr. Ir. Th. P. M. de Wit, Agricultural Attaché.

The hospitality of the Fundación de Ciencias Naturales La Salle, Campus de Margarita (Drs. J. J. Bocaranda, J. Otaola and H. Villegas) is gratefully acknowledged, as well as the assistance of captain and crew of the R. V. Doña Teresa (Punta de Piedras, Margarita).

\section{REFERENCES}

Stock, J. H., 1977. The taxonomy and zoogeography of the hadziid Amphipoda, with emphasis on the West Indian taxa. Stud. Fauna Curaçao, 55: 1-130.

- - 1982. Amsterdam Expeditions to the West Indian Islands, Report 18. Stygobiont Crustacea Malacostraca from geologically older and younger Antillean islands: a biogeographic analysis. Bijdr. Dierk., 52 (2): 191-199. 